_Elsőre meglepő,

utána belefeled-

kezik az ember, és

mindig új dolgot

fedez fel rajta. Igazi

különlegesség, amit

jó látni minden nap.

Hiányozna innen. |

(Szabó Ákos Péter)





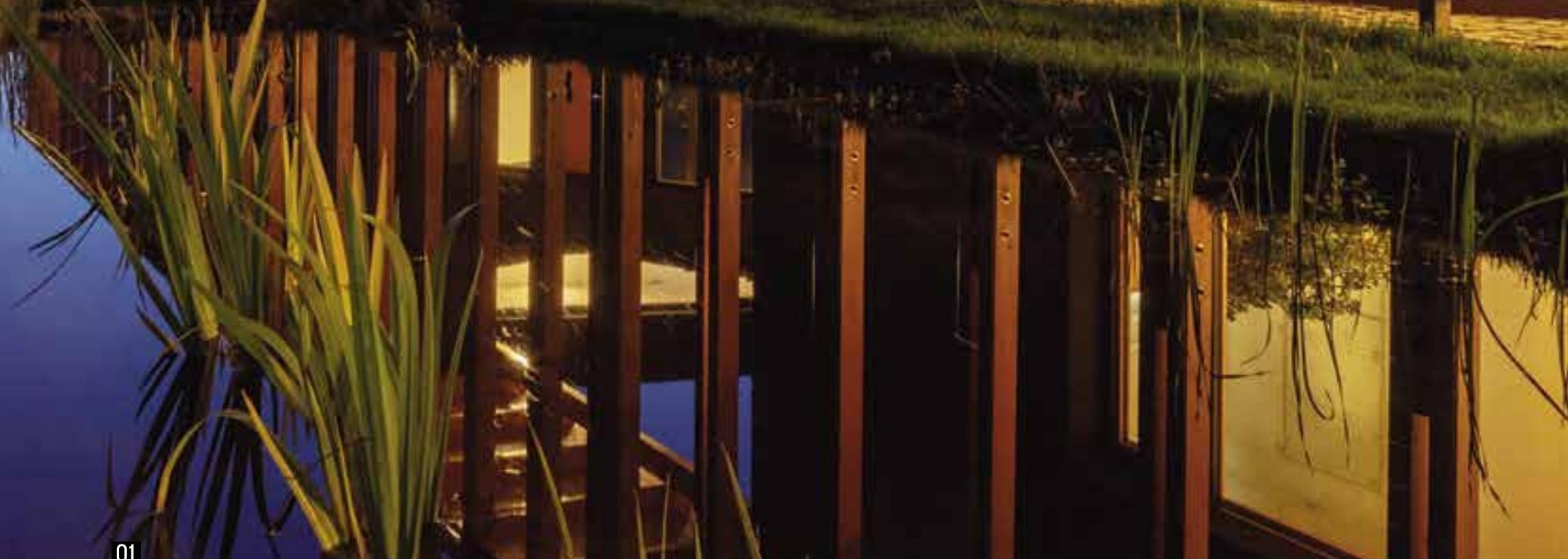




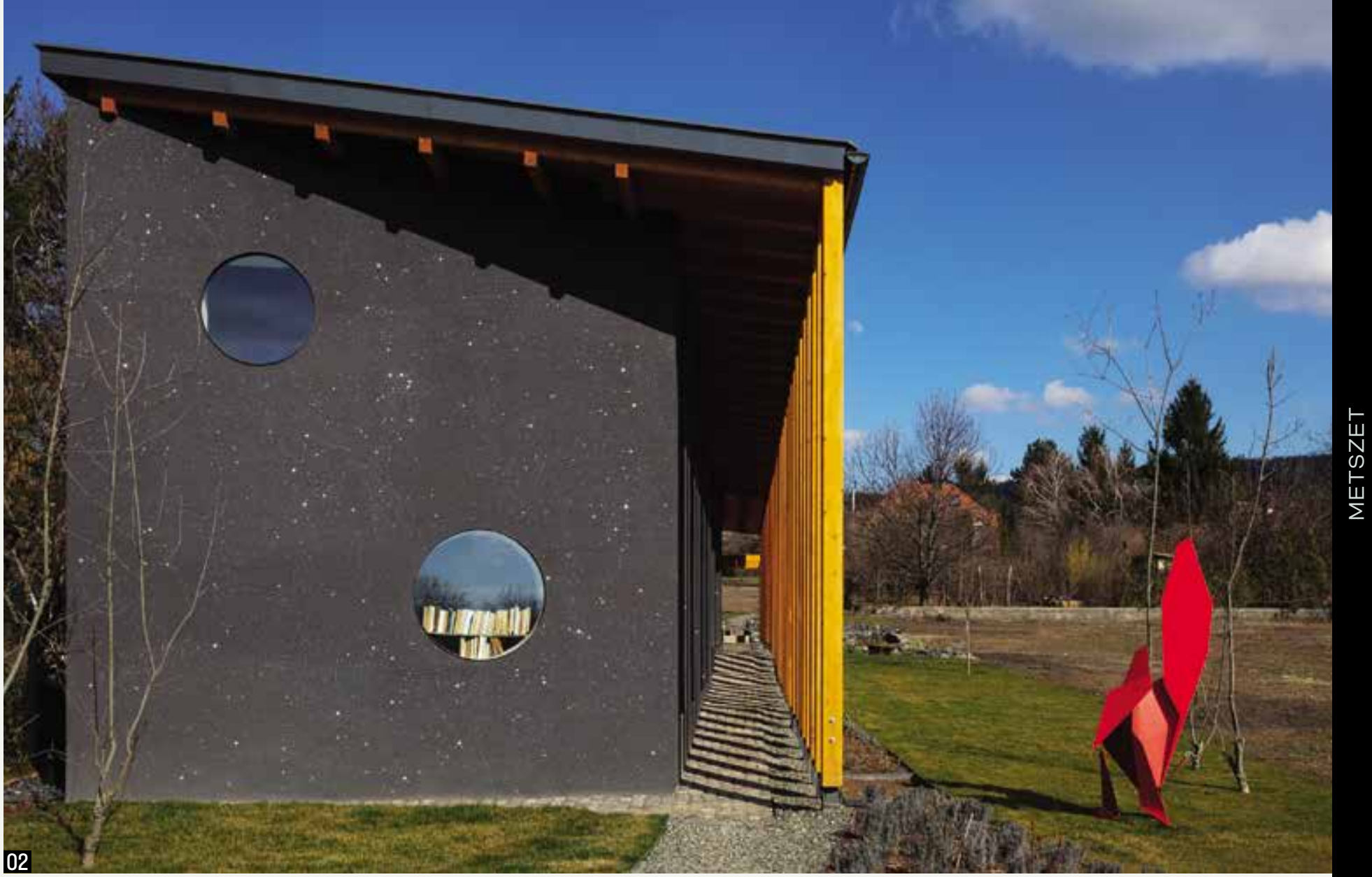

\section{A POSZTORGANIKUS ÉPÍTÉSZET UTÁN}

BÁRTFAI-SZABÓ GÁBOR CSALÁDI HÁZA | BUDAKESZ|

\begin{tabular}{ll|l}
\hline ÉPÍTÉSZ | & \\
Bártfai-Szabó Orsolya és Gábor & \\
& \\
SZERZŐ | & FOTÓ I \\
Wesselényi-Garay Andor & Bujnovszky Tamás & \\
\hline
\end{tabular}

01 A tornácos ház újraértelmezése született meg

02 Az utcai bütühomlokzat a hattagú családra utaló hat szelemennel
_ Lapunkban pár oldallal korábban már ismertettük Bártfai-Szabó Gábor minimumházát, amelyet típusként azonosítva a háromosztatú hosszúházak genealógiájába helyeztünk. A formai eltéréseken túl a „kisház” által felvetett problémát görgeti tovább saját családi háza, amely 2020 elején nagy feltűnést keltve mutatkozott be a szaksajtóban. [1; 2] A kedvező szakmai fogadtatás jele volt az is, ahogy Földes László egy, a házat ábrázoló fényképhez füzött megjegyzésében így írt: „ez most a kedvenc házam”. [3] Földes rokonszenve több mint érthető. Bártfai-Szabó háza éppúgy a típus és variációi mibenlétével foglalkozik, mint ahogy Földes jegyzett darabjai; éppúgy a kortársság mibenlétét firtatják, mint ahogyan archaikus gyökereiket sem tagadják el. Míg Bártfai-Szabó a formával mer nagyot húzni, addig Földes - mintegy utolsó mohikánként - a téglaregionalizmus nyújtotta lehetőségeket feszíti végletekig 


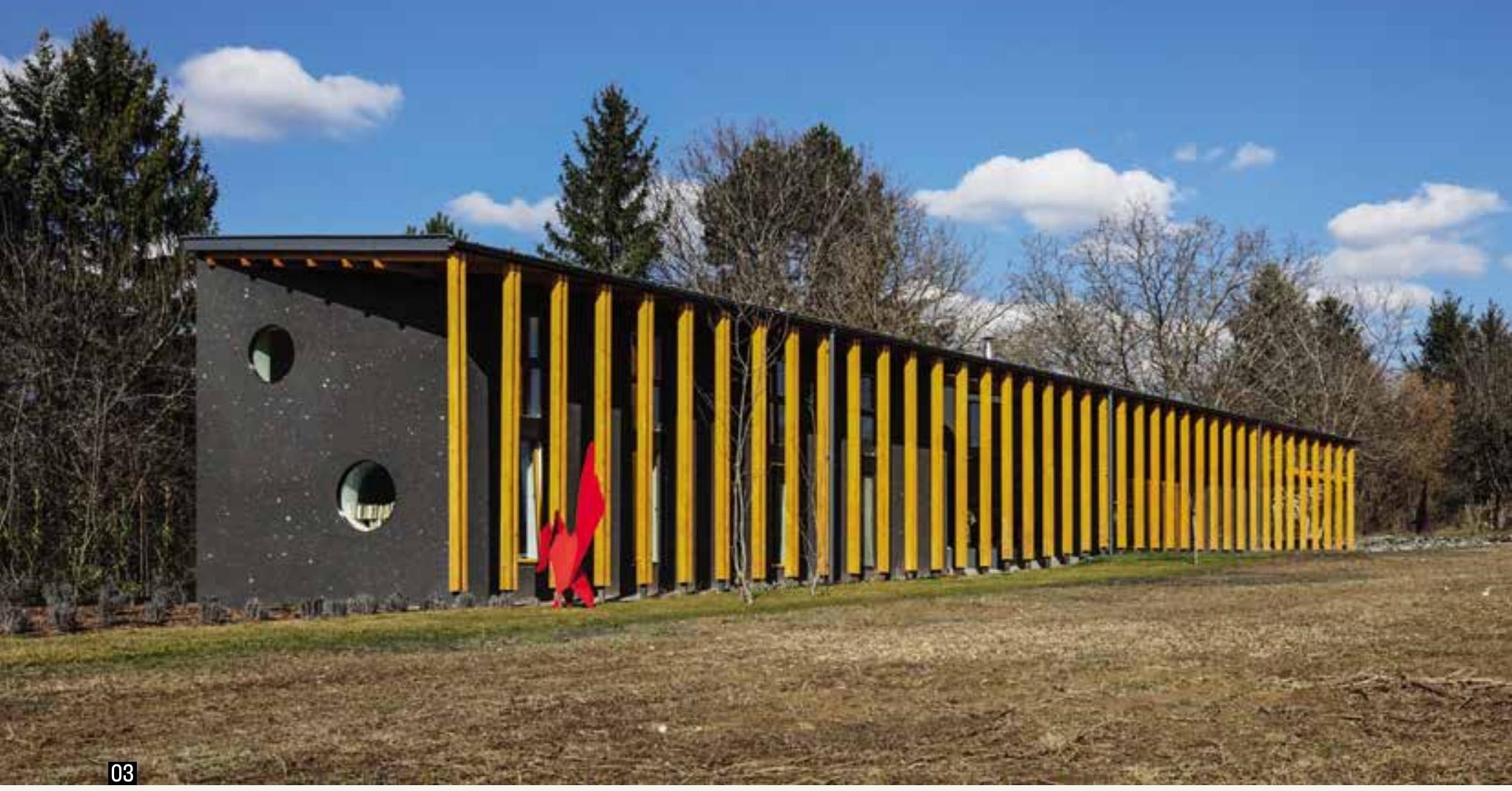

Buda-környéki családi házain. Megjegyzendő, amennyiben kitart a lassan attribútumává váló mániája mellett, a téglahasználati árapályok végén páratlanul egységes életmü lesz az övé. Csakhogy míg Földes László egy jól meghatározott építészeti genealógia mentén szervezi munkásságát, Bártfai-Szabó esetében ez a ház paradigma-, de legalábbis korszakváltás. A már említett és korábban bemutatott „kisház" ismeretében túlzás lenne azt állítani, hogy minden részletében előzmény nélküli, de eddigi karrierjének ismeretében inkább meglepő, semmint nyilvánvaló.

_ Ha stíluskohorszok mentén kellene szakmaszociológiai tablót festeni, akkor a most nyugdíjba vonuló generációt az organikusok és a fekete garbósok tömbjei határoznák meg. Előttük voltak az ipartervesek, a köztisek meg mindenki más, a jelenlegi középgeneráció pedig három nagymester alakja körül tünik csoportosulni: ők a Makovecz-árvák, a Janáky-özvegyek és a Kapy-óvoda. [4] Érdekes módon mindhárom szakmaszociológiai tömböt a hiány élményei határozzák meg. Makovecz Imre és Janáky István esetében a hátrahagyott űr, a betöltetlen tér vált nyomasztóvá, amihez pusztán csak adalék az a nagyon is tapintható tanácstalanság, amely előbbi esetében egy létező örökség követhetetlenségéből, utóbbiéban pedig örökség nélküli rajongásból fakad. A Kapy Jenő körül csoportosuló „yblis” fiatalok alapélménye ugyanakkor egy nagyon is konkrét kizáratottság: egyfajta elválasz tottság. Lehetett bármily tehetséges Bártfai-Szabó Gábor, Borsay Attila, Csontos Györgyi, Dienes Szabolcs, Kalmár László vagy Zsuffa Zsolt - csak így találomra, de névsorrendben -, főiskolai végzettségük elképzelhetetlenné tette, hogy az egyetemi diplomásokéhoz hasonló jogosultságaik legyenek. A lehetőségtől való institucionális elzáratottság, a klubból való intézményesített kirekesztettség a Kapykurzusok ígéretével együtt vezetett a kreatív energiák felszabadításához. Annak lehetősége, hogy „ti is igazi építészek lesztek”, vezette előbb a Vándoriskolára, majd az egyetemekre, végül pedig a Mesteriskolára és DLA-kurzusokra azokat a legtehetségesebbeket, akik magukat egymást között gyakran csak kőművesnek titulálták. A Vándor- és Mesteriskolák egymást kiegészítő képzései - tűnhettek azok bármenyire is eltérőnek gyakorlatukban vagy ideológiájukban - egyszerre ígérték a belépést egy közösségbe és egy klubba, miközben mindenki tudta, a tizenkilencedik ciklus nem lehet azonos a nyolcadikkal, mint ahogy a Nomád nemzedék sem a Csütörtöki Iskolával.

_ Több nemzedéktársához hasonlóan Bártfai-Szabó Gábor is végigjárta a szakmai képzés minden lehetséges fórumát és szerzett közvetlen tapasztalatot arról, milyen vándornak és „mesterisisnek” lenni. Ez a kettős képzettség voltaképp meglátszott eddigi házain is. Míves, de nem túl érdekes építészete egyszerre tanúskodott magas szakmai műveltségről és arról a tanácstalanságról, amely elkapott idővel oly sok Makovecz Imre által ihletett fiatalt. A kérdésbe foglalt talány úgy szólt, miképp lehet organikus építészetet csinálni az organikus építészet, de leginkább Makovecz Imre halála után. (Mint ahogy Janáky esetében akképp, miképp lehet építészetként továbbadni egy építészet nélküli élményhagyatékot.) 

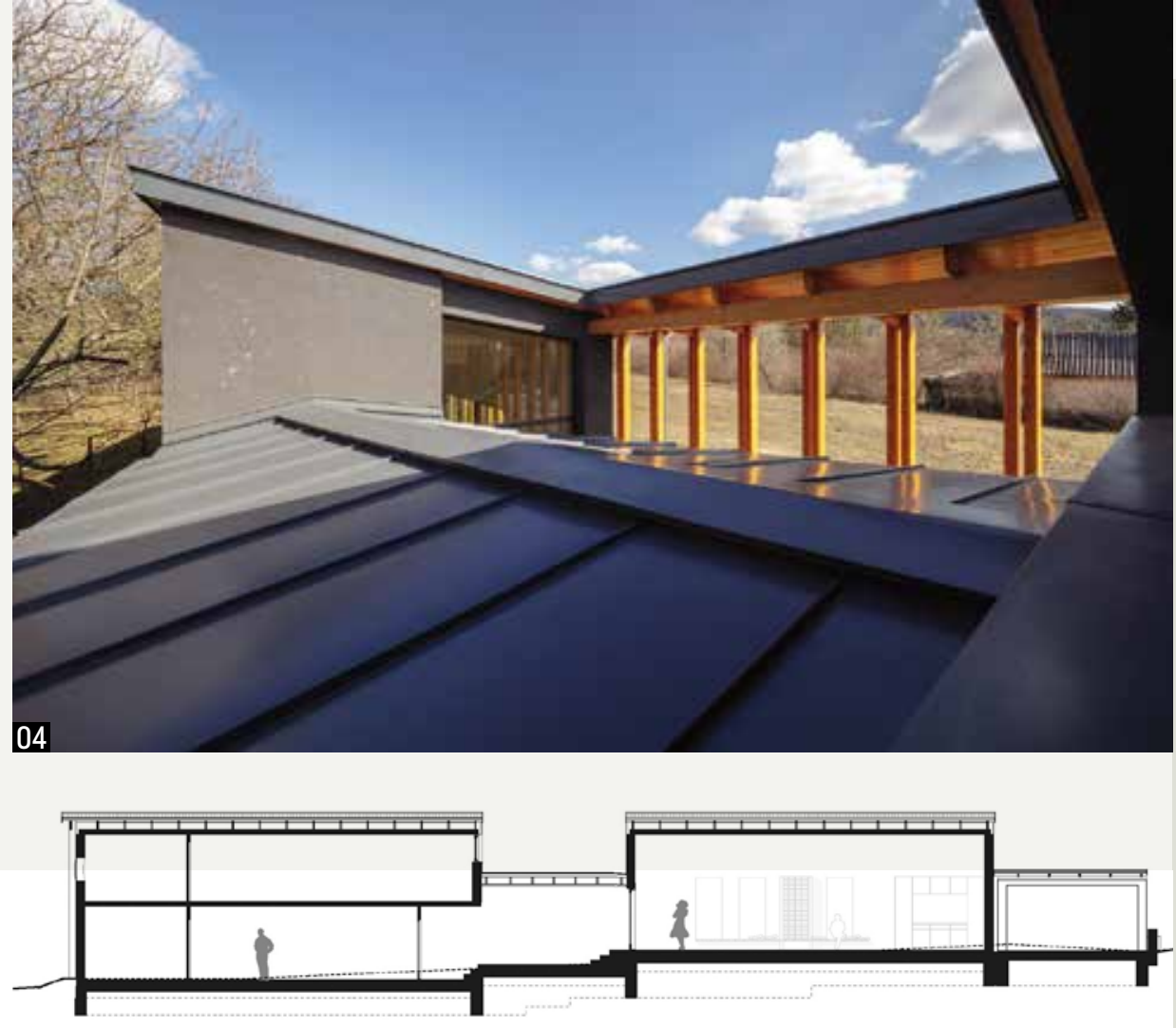

05
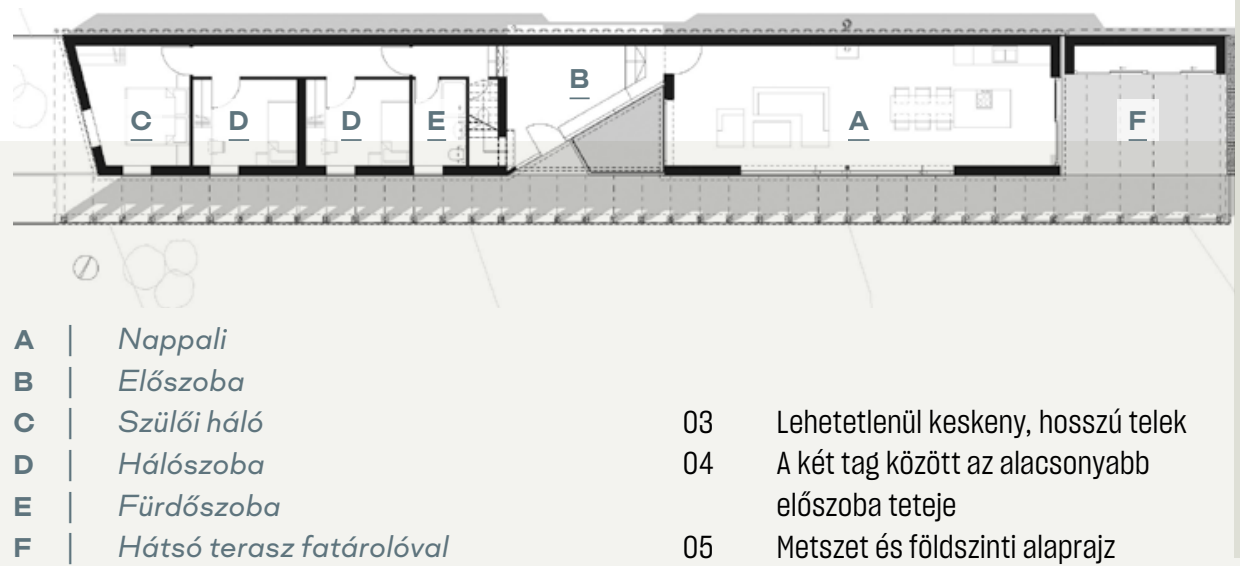

03

04

05
Lehetetlenül keskeny, hosszú telek A két tag között az alacsonyabb előszoba teteje Metszet és földszinti alaprajz
_Régóta ismerem Gábort, és mindig azt érzem nála, hogy szereti a funkcionálist és a környezetileg hatékonyt ötvözni valami meghökkentő motívummal vagy bátor megoldással. Így természetesnek találom, hogy a családi házuk előtt sem lehet elmenni szó nélkül. Amikor a házat megpillantom, az első gondolatom a döbbenetes arányaival kapcsolatos: hosszú és keskeny, mint egy pántlika. A fal antracit csillogása a szinte végtelen narancssárga árkádsor alatt megbabonázza az embert, ahogy halad a bejárat felé, ami pedig olyan, mint egy múvészeti alkotás azzal a pici „orsis” kertecskével a szegletében. De az igazi kellemes meglepetés odabenn vár az emberre: a ház szuper felosztása élő- és pihenőzónára. Látszik, hogy az élettér dominanciája és a pihenés intimitása fontos szempont volt barátaink számára. A nappali-konyha szép tágas, a vagány nyers betonfelületek ellenére meleg és hívogató, gyönyörűek a fények, amiket gazdagítanak a gondosan megtervezett kerti tavacska tükrén visszaverődve odabenn táncoló napsugarak is. Szeretek náluk lenni és fürdőzni ebben a meleg simogató fényben, hangulatban. Titkos vágyam, hogy egyszer lesz egy Bártfai-Szabó-házam. | (Hevesi Zsuzsanna, Budakeszi)
_ Makovecz Imre esetében a válasz egy olyan kontrateoretikus, kézműves építészetben csúcsosodott ki, amelynek központi figurái - saját szándékaiktól teljesen függetlenül - Nagy Tamás és Turányi Gábor lettek. Ez az építészet a téglát tette a mesterségbeli tudás szimbólumává, és olyasfajta együtteseket hozott létre, amelyek egyszerre váltak olvashatóvá a regionalizmus(ok) és az organikus építészet irányából. Éppúgy segített becsatornázni és ráncba szedni az olyan, kissé lázasabb alkotók fantáziáját, mint Turi Attila, mint ahogy - és erről úgyszintén sok cikk született - képes lett a földhöz kötni, regionális tulajdonságokkal felruházni az egyes házakat. A saját korukban, így különösképp Kenneth Frampton 200I-es magyar fordítása után kézenfekvő volt, hogy az akkor csúcsára járó hazai téglaépítészet a kritikai regionalizmussal azonosítsa önmagát, csakhogy mindez - mintegy Makovecz irtózatos gravitációjának ellensúlyozásaként - rendre kiegészült egy lábjegyzettel, amely a Mestertől való távolságot is hangsúlyozta. Avval, hogy a hazai téglaregionalizmus nemcsak önértéken, hanem egyben Makovecz ellenében is kénytelen volt meghatározni önmagát, szükségképp maradt abban a viszonyrendszerben, amelyet változatlanul az organikus építészettel kapcsolatos, hangsúlyozom, azt akár elutasító diskurzusok jellemeztek. Mindennek természetes következménye, hogy házeredményeik sem feltétlenül elválaszthatók oly mértékben az organikusokétól, mint ahogy az eredetileg szándékuk volt, így az interpretációs különbségek ellenére sem ördögtől való azokat a posztorganikus építészethez sorolni.

_ Jómagam ezt a fogalmat eredetileg leginkább azokra, a Bártfai-Szabó Gáboréhoz hasonló életművekre értettem, amelyek határozott vonalat kívántak húzni önmaguk és Makovecz Imre közé, úgy alkalmazva a mestertől tanult néhány müfogást, hogy közben értékként tekintették a fekete garbósok eredményeit. A mondat persze meg is fordítható. Mindez egy olyan intelligens, jól megcsinált házcsoportot eredményezett, amely inkább volt kulturált, semmint izgalmas. Ennek a sodornak a közepén helyezkedett el Bártfai-Szabó Gábor, kinek házai inkább mívesek voltak, semmint érdekesek, inkább esztétikaiak, semmint fogalmiak. Rajzai és megoldásai egy olyan építész portréját rajzolták, aki sok jó házat látott, tudja is, az milyen, és akar is 
_Tölünk légvonalban pár kilométerre egy rendkívüli házban laknak Gáborék. Korábban ő tervezte a mi házunkat is. A mostani időszak és az építés alatt is közös beszédtéma volt az akkori időszak. És volt pár együttes, szokásosan szórakoztató 'tervezési élmény'. Ahogy Gábor a nappalinkban kilépi az új ház nappalijának a méretét - ami persze végül nem olyan lett. A szokásos kávézónkban a csempe-- valójában cementlap- - árakon a közös hüledezés. A házak belmagasság-versenye - amit végül, azt hiszem, Gábor nyert. Aztán egyszer csak formát öltött a ház, ami amolyan komolyan rendkívüli. Tele számomra még papíron is kockázatos és vagány ötlettel. Strukturált, de emellett szabad és sohasem unalmas, mint amilyennek ismerem kedves barátomat és családját. I (Dr. Vántus Gergely, Budakeszi)

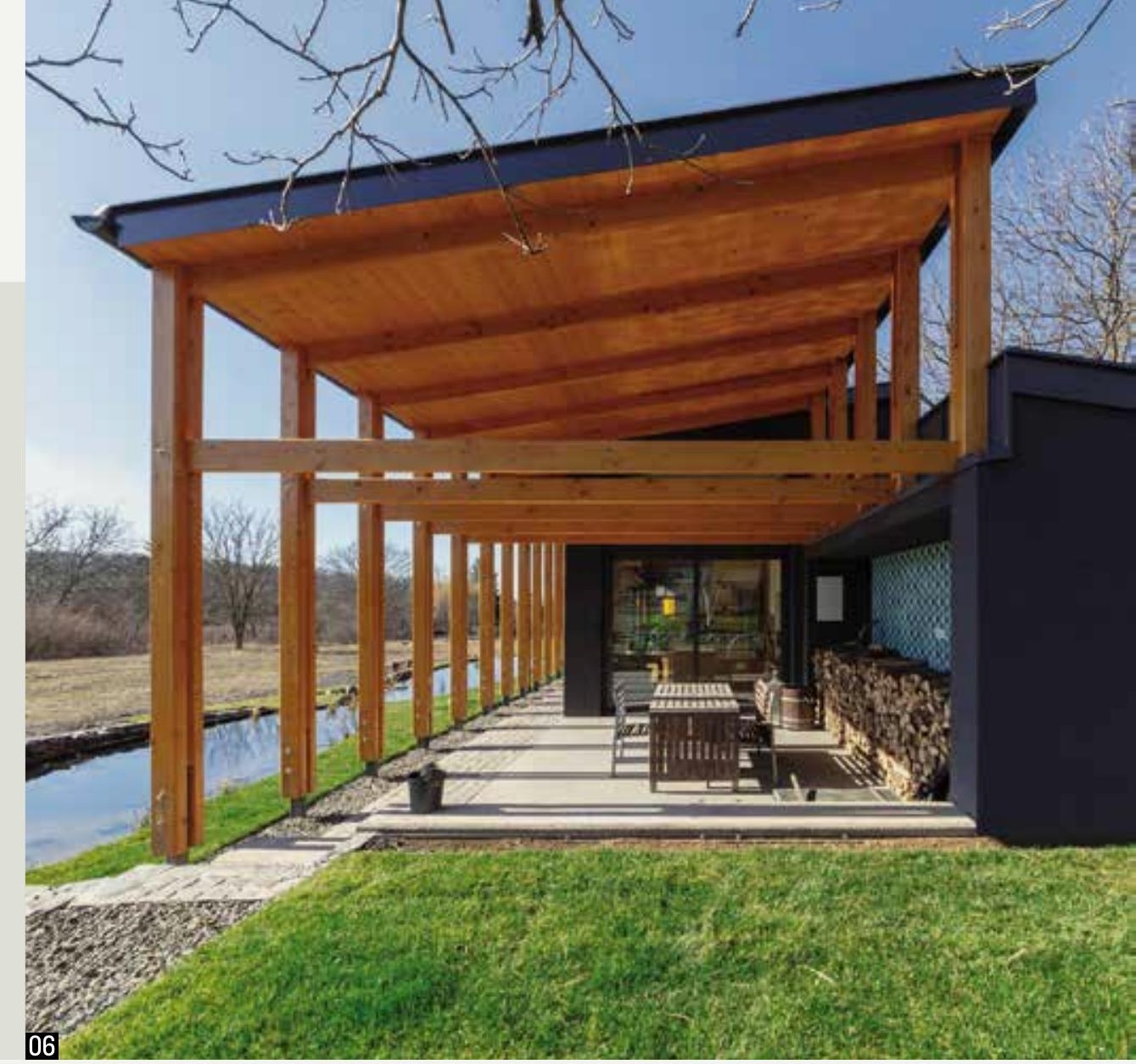

olyat csinálni. Összetett, anyagokkal is artikulált tömegek jellemezték ezt az építészetet, amelynek középpontjában a bontott tégla és annak manipulálásából eredő, alkalmasint affektáló részletek álltak.

_Egészen mostanáig.

_ Bevallom, engem lenyügöznek az itt publikált budakeszi házak, de küiönösen a sajátja által képviselt teljesítmény egyrészt azért, mert mer egy unalomig ismert típushoz nyúlni, másfelől pedig ezért, mert eközben már-már avantgárd gesztussal úgy rúgja fel a típus által nyújtott kereteket, hogy közben visszacsempészi a makoveczi örökségként is értelmezhető expresszivitást, saját életeseményei emlékeivé is téve ezáltal saját házát. Ráadásul - és ez különösképp fontos az építészetkritika szempontjából - mer hibázni is. _A képlet egyszerü. Egy szinte a lehetetlenségig keskeny telken épült fel a minden építész titkos álmaként megjelenő hosszúház. Súlypontban a tornácról nyitott bejárat: az utcai blokkba esnek a közlekedőfolyosóról feltárt fiúszobák a fürdővel, a folyosó végi tisztaszoba helyén a szülői hálóval. A kert felé nyúló szakaszban a nappali helyezkedik el a konyhával és a zöldbe nyíló terasszal. Az előszoba a dimenziók ellenére is tér: lehetetlen keskenysége ellenére kellő dramaturgiát biztosít a megérkezés élményéhez. Innen lépcső vezet az emeleti folyosóra, ahonnan - hasonlóképp a földszinti elrendezéshez - a lányszobák nyílnak. _ A nappali emelt belmagasságú, itt fraktálszerủen ismétlődik a háromosztatúság: „társalgó”, étkező és konyha egységei tagolják a nappalit, hogy az elrendezéshez eggyel nagyobb léptékü láncolatként kapcsolódjék a ház-teraszkert hármassága.

_ A kompozíciót a tornác és a tető fogja össze, megvalósítva Macalik Arnold bon mot-ját: „Ha van egy jó tetőd, az alatt sok disznóságot el lehet dugni.” Nem mintha szó lenne bármi ilyesmiről is. Épp ellenkezőleg: a bejáratnál szerencsésen válik el egymástól tető és térszerkezet, ha lehet, még analitikusabbá téve a két elem - fal és héj, tér és fedés - viszonyát.

_ Bevallom, épp a tető és az alatta szerveződő hátsó terasz viszonya kapcsán bukkan fel újra az a probléma, amelyre eddig nem sikerült megnyugtató megoldást találni. Ez pedig nem más, mint az archetípus, vagyis a háromosztatú hosszúház és környezetének kapcsolata. Ezek az épületek - Földes László remekbe szabott darabjaira is gondolva - egyértelmü és jól határolt testként állnak telkükön: tornáccal és terasszal együtt is világos határok jelzik a ház elejét és végét: az átmeneti terek egyértelműn a ház részei, nem pedig köztességek természet és építészet, test és üresség, kinn és benn között. Lehet bármily meggyőző is Budakeszin a tornác: az egy iránypontos perspektívák éppúgy hangsúlyozzák, mint a távolabbi felvételek, hogy ott járva bizony még a ház terében vagyunk. Nincs ez másképp a hátsó terasz esetében sem, amelyik azzal, hogy megkapja a maga markáns rúdstruktúráját, szükségképp adja fel a nappali lapszerű térszerkesztését, 




06

Hátsó terasz

07 A bejárati ajtó felsejlik a tornácoszlopok mögött

megakadályozva ezzel azt, hogy a két szoba akár kívülről, akár belülről tekintve egymásba, illetve a természetbe folyjék. Kötőtornác ide, kötőtornác oda: a terasz egyfajta toldalékként, addendumként létezik a nappali mellett, gyengítve azt a potenciált, amelyet a tető önszervező, egymásba illesztő ereje ígér, és a bejáratnál meg is valósít. Kissé másik irányból: az, ahogy ma, a mi éghajlatunkon a házat a telkére helyezzük, alapvetően táplálkozik Mies van der Rohe és Frank Lloyd Wright szerkesztéseiből, az általuk kikísérletezett áramló alaprajzból. Az általuk kidolgozott rendszer viszont eddig legalábbis alapvető ellentmondásban állt „ház”-hagyományaink agglutináló térszervezésével, sztereometrikus tömegével. A magyar parasztház nőhet ugyan a földből, tekinthető romantikus metaforákkal a táj részének, mégis, egyértelmủen elkülönböződik a tértől, amely körötte van. Testként, szoborként áll a természetben, mely szoborszerüséget, a parkban álló villa hagyományát itt Budakeszin a kerti fémplasztikák is hangsúlyozzák avval, hogy szükségképp teszik zöld posztamenssé környezetükben a telket. Elfogadom, hogy ez az ellentmondás csak engem érdekel, de azt is hiszem, érdemes lenne ezzel a jövőben tudatosan foglalkozni. Megismételve e lapszám A_pro’ rovatában írtakat, „ilyesfajta hosszúházat tervezni ma nem forma, hanem a választás
_ Szinte látom magam előtt az építkezni vágyók hosszú sorát, ahogy a keskeny, nagyon hosszú telekre legyintenek: „ide képtelenség normális házat tervezni". Erre jön az építész, akinek az építkezők álma, egy semmi kötöttséget sem tartalmazó négyszögletes telek kínzás lenne. A legyintők pedig nem értik, hogy lehetett ennyit kihozni ebből a helyszínből, ennyi ötletet, ennyi gondolatot, ennyire nem illeszkedőt és ennyire illeszkedőt egyszerre, ennyi díjat elnyerőt. Mert azok is lesznek, ne tévedjen senki... I (Horváth Zoltán építész) 


\section{ABSTRACTS}

\section{WESSELÉNYI-GARAY, Andor: AFTER POST ORGANIC ARCHITECTURE \\ Citation: Metszet, Vol 11, No 4 (2020), pp 11-17, DOI: 10.33268/Met.2020.4.1 \\ FAMILY HOME, BUDAKESZI, HUNGARY | Architect: Gábor and Orsolya BÁRTFAI-SZABÓ}

The regional tradition for developing linear rural homes has been reinvented for this family home. Referencing past works of respected Hungarian architects and the influence of studying under the Mesteriskola and
Vándoriskola programs guided this project's architect. The home is divided into clear functional elements, daytime, nighttime with transitional areas that are linked by a common veranda. This in theory follows the Hungarian rural tradition: to a point, after which the architectural language and use of materials follow a more contemporary vein.

VVARE-INAGT, UrSoIya: CUIVIVIUINITI DUILUIIVU

Citation: Metszet, Vol 11, No 4 (2020), pp 18-23, DOI: 10.33268/Met.2020.4.2

SAINT PETER'S CATHEDRAL, WORMS, GERMANY | Artworks by: Anna HERINGER and Martin RAUCH

In this project to redesign of liturgical spaces in a cathedral the community came together with artists to create rammed earth furnishings: the pulpit, altar and prayer stands amongst others. Instead of cement, here clay was put to the task to strengthen the rammed earth structures, meaning all materials were taken directly from nature. The link between nature and human activity being implemented at this level also helps to inform everyone that the so-called sophistication of western ideals does not really differ from out poorer counterparts elsewhere. Creativity is a proof of the brotherhood of man.

\section{GUTAI, Mátyás: TRADITION BALANCE}

Citation: Metszet, Vol 11, No 4 (2020), pp 24-29, DOI: 10.33268/Met.2020.4.3

\section{ODUNPAZARI MODERN MUSEUM, TURKEY | Architects: KENGO KUMA}

Kengo Kuma's museums always reinterpret local tradition, and his new work in Turkey, Odunpazari Modern Museum is another example of this design approach. Wooden architecture has great tradition in Turkey, so Kengo Kuma chose this material, which results in a playful appearance with horizontal wooden lamels and light filtering through. Not only the facades, but the floor plan was also influenced by vernacular architecture, hence the rotated building masses that also create new, contemporary public spaces.

\section{GIUSTRA, Martina: AZULEJO, REVITALIZATION, RENZO PIANO}

Citation: Metszet, Vol 11, No 4 (2020), pp 30-33, DOI: 10.33268/Met.2020.4.4

PRATA HOUSING COMPLEX, LISBON, PORTUGAL | Architects: RPBW, RENZO PIANO

Originally conceived just over twenty years ago the Prata Housing complex in Lisbon has finally moved ahead. Designed to be an energy aware redevelopment on a brown field, site where technical development of these residential units addresses issues of public and private spaces, orientation and azulejo a nod towards the regional use of azulaj tiles. The obvious similarity between locally produced ceramic tiles and the not intended decorative repetition of solar cells lead towards the development of a high tech azulej solar roof system, which generates energy, opens for means of ventilation and serves as a blue on white decorative motif.

\section{WETTSTEIN, Domonkos: STRUCTURAL DYNAMICS: ŐRMEZŐ CITY GATE}

Citation: Metszet, Vol 11, No 4 (2020), pp 34-39, DOI: 10.33268/Met.2020.4.5

BUDAPEST ONE OFFICE BUILDING, BUDAPEST, HUNGARY | Architects: Gergely PAULINYI, András REITH and István VÁMOSSY

Rust Belt redevelopment has led to the increase of flagship commercial building projects at key points along main arterial roads and railways into major cities.

Environmental impact and sustainability guided the design team towards an innovative use of generative design analysis which treats the building as a design object arrived at by the application of computable algorithms. The final result being a complex geometric form where controlled assessment of daylighting, ventilation and user patterns assisted in creating a free-flowing outer shell.

\section{BIHARI, Ádám - MEDGYASSZAY, Péter: PRESENT ADOBE CONSTRUCTION AND EXPECTED FUTURE TENDENCIES}

Citation: Metszet, Vol 11, No 4 (2020), pp 40-43, DOI: 10.33268/Met.2020.4.6

The construction industry faces many challenges over the next decade. Adobe or to be more accurate earth-based construction methods are limited when applied to traditional brick and wall finishes, yet with the advance of technology prefabricated or robotic solutions offer a viable way forward. Both traditional and future technologies will need to be regulated and monitored correctly considering financial, social and environmental impact. Once this is achieved embarking upon a path forwards can easily occur.

KONDOR, Tamás - JUHÁSZ Hajnalka: HUNGARIAN NEST

Citation: Metszet, Vol 11, No 4 (2020), pp 44-47, DOI: 10.33268/Met.2020.4.7

NEW TYPES OF ENERGY SPACES IN SUSTAINABLE ARCHITECTURE

Developing ideas explored in the Solar Decathlon competition the reality of exploring how to improve on the Hungarian cube-like house type with the hope of expanding upon the use of vernacular elements to create a low-cost passive housing typology. Here the external and intermediate spaces have been included in the generation of a successful microclimatic experiment. Zoning of a home from private to public has proven to hold environmental impact solutions for energy positive homes.

MATOLCSY, Károly - TERJÉK, Anita - ZAJÁROS, Anett: REMOURBAN: SMART CITIES AND COMMUNITIES

Citation: Metszet, Vol 11, No 4 (2020), pp 48-51, DOI: 10.33268/Met.2020.4.8 METHODS, RESULTS, GOOD PRACTICE AND LESSONS

The EU project, Regeneration Model for accelerating the smart URBAN transformation, consists of 22 partnerships across 7 member states. Three existing city projects: Nottingham, Tepebaşi and Valladolid have returned positive results, now the project will be further expanded to the cities of Seraing and Miskolc. To date projects have focused upon smart infrastructure from the point of view of energy consumption, in Miskolc this will be extent towards public utilities and urban public transport. 